\title{
Obesity and dyslipidemia in patients with psoriasis treated at a dermatologic clinic in Manaus
}

\author{
Obesidade e dislipidemia em pacientes com psoríase atendidos num \\ ambulatório de dermatologia de Manaus
}

\author{
Mônica Santos ${ }^{1}$ \\ Gabriela Piraice Gomes²
}

Hannah Monteiro Fonseca ${ }^{2}$
Andrea de Souza Cavalcante

Alex Panizza Jalkh ${ }^{3}$

DOI: http://dx.doi.org/10.1590/abd1806-4841.20132090

\begin{abstract}
BACKGROUND: Psoriasis is a chronic inflammatory disease of multifactorial etiology, with participation of genetic, autoimmune and environmental factors. Recent studies have demonstrated the role of inflammatory cells and mediators in the pathogenesis of psoriasis, which is now defined as a systemic and autoimmune inflammatory disease that may be associated with other diseases of inflammatory nature. OвJECTIVEs: To evaluate the occurrence of obesity and dyslipidemia in patients with psoriasis treated at a dermatology clinic in Manaus. METHODs: We performed a prospective descriptive study to assess the prevalence of obesity and dyslipidemia in patients with psoriasis. Besides the recommended dermatological care, a physical examination was performed to measure weight, height and waist circumference. RESULTS: We included 72 patients, $44(61.1 \%)$ female and $28(38.9 \%)$ male, with a mean age of 51.0 years \pm 15.9 years. As for body mass index (BMI), 16 $(22.2 \%)$ were overweight and $20(27.8 \%)$ were obese. In the analysis of waist circumference in relation to gender, we found that $79.5 \%$ of women surveyed had central obesity, a percentage statistically higher than that observed among men (42.9\%) at the $5 \%$ level of significance $(p=0.001)$. Regarding the diagnosis of dyslipidemia, $29(65.9 \%)$ females and $22(78.6 \%)$ males showed alterations in lipid profile. ConCLUSIONS: The occurrence of dyslipidemia and obesity in patients with psoriasis can affect life quality and expectancy, increasing the risk of systemic and metabolic diseases, which makes periodic investigation of these comorbidities in patients with psoriasis mandatory.
\end{abstract}

Keywords: Dyslipidemias; Obesity; Psoriasis

Resumo: Fundamentos: A psoríase é uma doença inflamatória crônica, com etiologia multifatorial, com participação de fatores genéticos, auto-imunes e ambientais. Estudos recentes demonstram o papel de células e mediadores inflamatórios na patogênese da psoríase, que passou a ser definida como uma afecção inflamatória sistêmica e auto-imune, podendo associarse a outras doenças de natureza inflamatória. OвJETIVOS: Avaliar a ocorrência de obesidade e dislipidemia em pacientes com psoríase atendidos num ambulatório de dermatologia de Manaus. MÉTodos: Foi realizado estudo descritivo e prospectivo para avaliar a ocorrência de obesidade e dislipidemia em pacientes com psoríase. Além do atendimento dermatológico preconizado, foi realizado exame físico com medida de peso, altura e circunferência abdominal. RESULTADOs: Foram incluídos 72 pacientes, sendo $44(61,1 \%)$ do sexo feminino e 28 (38,9\%) do sexo masculino, com média de idade de 51,0 anos $\pm 15,9$ anos. Quanto ao índice de massa corporal, 16 (22,2\%) apresentavam sobrepeso e 20 (27,8\%), obesidade. Na análise da circunferência abdominal em relação ao gênero, observou-se que 79,5\% das mulheres examinadas apresentavam obesidade central, percentual estatisticamente maior que o observado entre os homens $(42,9 \%)$, ao nível de $5 \%$ de significância ( $p=0,001)$. Em relação ao diagnóstico de dislipidemia, 29 (65,9\%) do sexo feminino e 22 (78,6\%) do masculino apresentaram alteração no lipidograma. ConCLUSÕES: A ocorrência de dislipidemia e obesidade nos pacientes com psoríase pode alterar a qualidade e expectativa de vida, aumentando o risco de doenças sistêmicas e metabólicas, o que torna obrigatória a investigação periódica dessas comorbidades nos portadores de psoríase.

Palavras-chave: Dislipidemias; Obesidade; Psoríase

Received on 27.08.12.

Approved by the Advisory Board and accepted for publication on 23.01.2013.

* Work carried out at the Dermatology Clinic of the Tropical Medicine Foundation (Fundação de Medicina Tropical Dr. Heitor Vieira Dourado - FMTAM) - Manaus (AM), Brazil.

Financial support: This work received financial support from the Amazonas Research Foundation (Fundação de Amparo à Pesquisa do Amazonas - FAPEAM). Conflict of interests: none.

MD, PhD in Tropical Medicine - Dermatologist at the Alfredo da Matta Foundation (Fundação Alfredo da Matta - FUAM). Professor of dermatology at the State University of Amazonas (Universidade do Estado do Amazonas - UEA) - Manaus (AM), Brazil.

Medical student at the State University of Amazonas (Universidade do Estado do Amazonas - UEA) - Manaus (AM), Brazil.

MD, Master's degree in infectious and parasitic diseases - Dermatologist at the Tropical Medicine Foundation (Fundação de Medicina Tropical Dr. Heitor Vieira Dourado - FMTAM) - Manaus (AM), Brazil.

MD, Dermatologist - Dermatologist at the Tropical Medicine Foundation (Fundação de Medicina Tropical Dr. Heitor Vieira - FMTAM) - Manaus (AM), Brazil. 


\section{INTRODUCTION}

Psoriasis is a chronic inflammatory disease that may affect the skin, joints, nails and scalp. ${ }^{1}$ It has a multifactorial etiology, with participation of genetic, autoimmune and environmental factors. ${ }^{2,3,4}$ Recent studies have demonstrated the role of inflammatory cells and mediators in the pathogenesis of psoriasis, which is now defined as a systemic and autoimmune inflammatory disease that may be associated with other inflammatory diseases, such as diabetes mellitus, obesity, cardiovascular diseases, hypertension and dyslipidemias., ${ }^{5,6}$ As of the eighties, epidemiological studies began to show the association between psoriasis and obesity. ${ }^{78}$ More recently, studies have demonstrated that in obesity there is a mild inflammatory status, with increased levels of TNF- $\alpha$ and IL-6, which might trigger or exacerbate psoriatic lesions. ${ }^{9}$ On the other hand, studies reveal that patients with psoriasis have a greater chance of developing obesity due to metabolic unbalance derived from the chronic proinflammatory status. ${ }^{10,11}$ Other works suggest the association between psoriasis and abnormalities in serum lipid concentrations. ${ }^{12,13}$ Psoriasis patients usually have a proatherogenic profile, with hypertriglyceridemia, elevation of LDL and VLDL concentrations and decrease of serum HDL levels. All of these factors justify routine investigation and early treatment of these comorbidities, to offer psoriasis patients an enhanced quality of life.

\section{Objectives}

Assess the occurrence of dyslipidemia and obesity in patients with psoriasis treated at an outpatient dermatology clinic in a reference hospital of Manaus.

\section{METHODS}

A descriptive and prospective study was conducted to assess the occurrence of dyslipidemia and obesity in patients with psoriasis treated at a reference outpatient dermatology clinic, during the period between September 2011 and June 2012. The inclusion of patients and sample size were established through spontaneous demand. All patients included underwent a physical examination and weight, height and abdominal circumference were measured. The abdominal circumference measure was taken at half the distance between the iliac crest and the lower costal margin. Weight and height measures were used for calculation of the body mass index by means of the formula BMI $=$ Weight $/$ Height $^{2}$. WHO criteria for obesity definition were used (Overweight: BMI between 25 and 29.99; Obese Class I: BMI between 30 and 34.9; Obese Class II: 35 to 39.9; Obese Class III: BMI $\geq 40$ ). Abdominal circumference measure over $88 \mathrm{~cm}$ in women and $102 \mathrm{~cm}$ in men was defined as central obe- sity. Dyslipidemia was defined as Total serum cholesterol $>240 \mathrm{mg} / \mathrm{dL}$; HDL cholesterol $<40 \mathrm{mg} / \mathrm{dL}$ in men and $<50 \mathrm{mg} / \mathrm{dL}$ in women; triglycerides $>150$ $\mathrm{mg} / \mathrm{dL} ; \mathrm{LDL}>160 \mathrm{mg} / \mathrm{dL}$. Patients answered a questionnaire about the clinical picture of the disease, prior pathology history and lifestyle habits, such as cigarette smoking, alcohol consumption and regular practice of physical exercise. A complete lipid profile was also requested and patients were oriented to have the sample collected after a 12 hour- fast. Those with dyslipidemia or obesity diagnosis were referred for joint follow-up with an endocrinologist.

\section{Statistical Analysis}

The statistical analysis was done by calculating absolute and relative frequencies. For the central tendency measures, the mean, median and standard deviation (SD) were calculated. In the analysis of categorical variables the Chi Square test of Pearson was used; in cases where this was not feasible, Fisher exact test was applied. The comparison of means was done by applying the Student's t test when data presented normal distribution and the nonparametric MannWhitney test, when the normality assumption was not guaranteed. The software used for analysis was EpiInfo version 3.5.3 for Windows and the test significance level was established as 5\%.

\section{Ethical Aspects}

This study was approved by the Research Ethics Committee of the Tropical Medicine Foundation Dr. Heitor Vieira Dourado, under number CAE 0035.0.114.000-11.

\section{RESULTS}

Seventy-two patients were included, 44 (61.1\%) female and $28(38.9 \%)$ male, with a mean age of 51.0 years \pm 15.9 years. The median time for psoriasis diagnosis was 5.0 years, varying from 1 month to 20 years (Table 1). The most frequently found clinical form of the disease was psoriasis vulgaris, with small and large plaques. Of the 72 patients, 21 had concomitant joint involvement and four had nail involvement exclusively. As regards the treatments employed, 14 patients used only topical medications and 58 systemic therapy (32 used methrotrexate, 18 acitretin, two cyclosporine and six immunobiologics). In relation to prior pathology history, 25 (34.7\%) had hypertension and 14 (19.4\%) were being treated for diabetes. In the comparison of median time since diagnosis regarding prior diagnosis of diabetes, a statistically significant difference was found in comparison with patients that did not present this comorbidity (Table 2). As for the body mass index (BMI), 16 (22.2\%) pre- 
sented overweight and $20(27.8 \%)$ were obese. The abdominal circumference measure analysis related to gender revealed that $79.5 \%$ of the women examined presented central obesity, a percentage statistically higher than that found among men $(42.9 \%)$, at the $5 \%$ significance level $(p=0.001)$. Regarding the dyslipidemia diagnosis, $29(65.9 \%)$ of the females and 22 $(78.6 \%)$ of the males presented lipid profile alterations (Table 3). Of the patients with dyslipidemia, eight had high total cholesterol, 35 high triglycerides and six, high LDL. As for HDL cholesterol, 28 female and 16 male patients presented HDL lower than 50 $\mathrm{mg} / \mathrm{dL}$ and $40 \mathrm{mg} / \mathrm{dL}$, respectively (Table 4 ). Of the 51 patients with dyslipidemia, eight $(15.7 \%)$ were cigarette smokers, twelve $(23.5 \%)$ were alcohol consumers and only eight $(15.7 \%)$ practiced regular physical exercise. Of the 20 patients with obesity according to the BMI, only two (10.0\%) practiced physical exercises regularly, six $(30.0 \%)$ were alcohol consumers and nine $(45.0 \%)$ were smokers. Of the 72 patients, six $(8.3 \%)$ had HIV/AIDS and two of them had been using antiretroviral therapy for more than two years. Only one of them presented dyslipidemia.

TABLE 1: Distribution according to frequency of sociodemographic data and time since diagnosis of the disease in patients with psoriasis included in the study

\begin{tabular}{lll}
\hline $\begin{array}{l}\text { Variable } \mathbf{n = 7 2} \\
\text { Gender }\end{array}$ & $\mathbf{f 1}$ & $\%$ \\
$\begin{array}{l}\text { Female } \\
\text { Male }\end{array}$ & 44 & 61.1 \\
& 28 & 38.9 \\
Age (years) & & \\
$<25$ & & \\
$25 \mid---35$ & 3 & 4.2 \\
$35 \mid---45$ & 8 & 11.1 \\
$45 \mid--55$ & 15 & 20.8 \\
$55 \mid--$ 65 & 13 & 18.1 \\
$\geq 65$ & 19 & 26.4 \\
Mean \pm SD & 14 & 19.4 \\
& $51.0 \pm 15.9$ \\
Time since diagnosis (years) & & \\
$<01$ & 13 & \\
$01 \mid---05$ & 19 & \\
$05 \mid---10$ & 15 & \\
$10 \mid---20$ & 17 & \\
$\geq 20$ & 8 & \\
Median & & \\
Q1-Q3 & 5.0 \\
& $01-10$
\end{tabular}

TABLE 2: Distribution according to median time since diagnosis regarding hypertension and diabetes mellitus in patients with psoriasis included in the study

\begin{tabular}{lllll}
\hline $\begin{array}{l}\text { Variables (n=72) } \\
\text { Hypertensive }\end{array}$ & $\mathbf{n}$ & Median & Q1 - Q3 & $\mathbf{p}^{*}$ \\
Yes & 25 & 8.0 & $1-12$ & \\
No & 47 & 3.0 & $1-10$ & \\
Diabetes & & & & $\mathbf{0 . 0 4 1}$ \\
Yes & 14 & 8.5 & $6-11$ & \\
No & 58 & 3.0 & $1-10$ & \\
\hline
\end{tabular}

$\mathbf{f}^{1}=$ simple absolute frequency. ${ }^{*}$ Chi Square Test of Pearson. Value of $\mathrm{p}$ in bold indicates statistical association at the $5 \%$ significance level

TABLE 3: Distribution according to gender frequency in relation to results of BMI, Abdominal Circumference and Dyslipidemia in patients with psoriasis included in the study

\begin{tabular}{|c|c|c|c|c|c|c|}
\hline & Gender & & & & & \\
\hline Physical & Female & Male & & & & \\
\hline Examination & $(\mathrm{n}=44)$ & $(\mathrm{n}=28)$ & & & & \\
\hline & $\mathrm{f}_{1}$ & $\%$ & $f_{1}$ & $\%$ & Total & $\mathrm{p}^{*}$ \\
\hline Obesity (IMC $\geq 30)$ & & & & & & 0.904 \\
\hline Yes & 12 & 16.7 & 8 & 11.1 & 20 & \\
\hline Overweight (IMC & $25-29.9)$ & & & & & 0.803 \\
\hline Yes & 10 & 13.8 & 6 & 8.3 & 16 & \\
\hline Abdominal & & & & & & \\
\hline Circumference & & & & & & 0.001 \\
\hline Obese & 35 & 79.5 & 12 & 42.9 & 47 & \\
\hline Normal & 9 & 20.5 & 16 & 57.1 & 25 & \\
\hline Dyslipidemia & & & & & & 0.249 \\
\hline Yes & 29 & 65.9 & 22 & 78.6 & 51 & \\
\hline No & 15 & 34.1 & 6 & 21.4 & 21 & \\
\hline
\end{tabular}

$\mathrm{f}_{1}=$ simple absolute frequency. ${ }^{*}$ Chi Square Test of Pearson. Value of $\mathrm{p}$ in bold indicates statistical association at the $5 \%$ significance level

TABLE 4: Distribution according to frequency of laboratory data in patients with psoriasis included in the study

\begin{tabular}{lll}
\hline Variables $(\mathbf{n + 7 2})$ & $\mathbf{f 1}$ & $\mathbf{\%}$ \\
Cholesterol >240 & 8 & 11.1 \\
Yes & 64 & 88.9 \\
No & & \\
HDL <50 in Women $(\mathbf{n + 4 4 )}$ & 28 & 63.6 \\
Yes & 16 & 36.4 \\
No & & \\
HDL < 40 in Men $(\mathbf{n}=\mathbf{2 8})$ & 16 & 57.1 \\
Yes & 12 & 42.9 \\
No & & \\
Triglycerides $>\mathbf{1 5 0}$ & 35 & 49.3 \\
Yes & 36 & 50.7 \\
No & & \\
LDL $>\mathbf{1 6 0}$ & 6 & 8.3 \\
Yes & 66 & 91.7 \\
No & & \\
\hline
\end{tabular}




\section{DISCUSSION}

Psoriasis is currently defined as an inflammatory and autoimmune skin disease, that may progress with articular manifestations and systemic comorbidities. ${ }^{14}$ The cause for association between psoriasis and these comorbidities has still not been fully elucidated, but studies point to a chronic proinflammatory status. This proinflammatory status is mediated by $\mathrm{T}$ lymphocytes, especially $\mathrm{T}$ helper 1 (Th-1) lymphocyte, which produces inflammatory cytokines, as the tumor necrosis factor $\alpha$ (TNF- $\alpha$ ), interleukin 2 (IL2) and interferon $\Upsilon$ (IFN- $\Upsilon$ ). ${ }^{15}$ Other studies show that these comorbidities occur more often in psoriatic patients who are in an older age group, with longer time of disease progression, as well as in moderate and severe forms of the disease. ${ }^{16}$ Of the 72 patients with psoriasis included in the study, $51(70.8 \%)$ presented dyslipidemia, 20 obesity (27.8\%) and 47 (65.2\%) central obesity; these had a longer time of psoriasis progression than patients who did not have these comorbidities. The above data coincide with what was found in the literature, demonstrating that the time of psoriasis progression increases chances for development of metabolic alterations (Table 5). Other factors seem to play a relevant role in the onset of obesity and dyslipidemia in psoriasis patients, such as sedentary lifestyle, smoking habit and alcohol consumption. Of the 20 patients who were obese according to the BMI, only two $(10.0 \%)$ practiced physical exercises regularly, six $(30.0 \%)$ were alcohol consumers and nine

\section{REFERENCES}

1. Gudjonsson JE, Elder JT. Psoriasis: epidemiology. Clin Dermatol. 2007;25:535-46.

2. Nickoloff BJ, Qin JZ, Nestle FO. Immunopathogenesis of psoriasis. Clin Rev Allergy Immunol. 2007;33:45-56.

3. Griffiths CE, Barker JN. Pathogenesis and clinical features of psoriasis. Lancet. 2007;370:263-71.

4. Naldi L, Chatenoud L, Belloni A, Peserico A, Balato N, Virgili AR, et al. Medical history, drug exposure and the risk of psoriasis. Evidence from an Italian case-control study. Dermatology. 2008;216:125-30.

5. Lindegård B. Diseases associated with psoriasis in a general population of 159,200 middle-aged, urban, native Swedes. Dermatologica. 1986;172:298-304.

6. Nijsten T, Wakkee M. Complexity of the association between psoriasis and comorbidities. J Invest Dermatol. 2009:129:1601-3.

7. Kimball $A B$, Wu Y. Cardiovascular disease and classic cardiovascular risk factors in patients with psoriasis. Int J Dermatol. 2009;48:1147-56.

8. Nisa N, Qazi MA. Prevalence of metabolic syndrome in patients with psoriasis. Indian $J$ Dermatol Venereol Leprol. 2010;76:662-5.

9. Mebazaa A, El Asmi M, Zidi W, Zayani Y, Cheikh Rouhou R, El Ounifi S, et al. Metabolic syndrome in Tunisian psoriatic patients: prevalence and determinants. J Eur Acad Dermatol Venereol. 2011;25:705-9.

10. Mallbris L, Granath F, Hamsten A, Ståhle M. Psoriasis is associated with lipid abnormalities at the onset of skin disease. J Am Acad Dermatol. 2006;54:614-21.

11. Duarte GV, Follador I, Cavalheiro CM, Silva TS, Oliveira Mde F. Psoriasis and obesity: literature review and recommendations for management. An Bras Dermatol. 2010;85:355-60.
TABLE 5: Distribution according to median of time since diagnosis regarding BMI, abdominal obesity and dyslipidemia in patients with psoriasis included in the study

\begin{tabular}{lllll}
\hline $\begin{array}{l}\text { Variables (n=72) } \\
\text { Obesity (BMI > 30 }\end{array}$ & $\mathbf{n}$ & Median & $\mathbf{Q}_{\mathbf{1}}-\mathbf{Q}_{\mathbf{3}}$ & $\begin{array}{l}\mathbf{P}^{*} \\
\mathbf{0 , 7 1 4}\end{array}$ \\
Yes & 20 & 5.0 & $1-11$ & \\
No & 52 & 5.0 & $1-10$ & \\
Abdominal Obesity & & & & $\mathbf{0 . 0 2 2}$ \\
Yes & 47 & 7.0 & $1-10$ & \\
No & 25 & 1.0 & $0-10$ & \\
Dyslipidemia & & & & $\mathbf{0 . 1 3 2}$ \\
Yes & 51 & 8.0 & $1-12$ & \\
No & 21 & 3.0 & $1-5$ & \\
\hline
\end{tabular}

$\mathrm{f}_{1}=$ simple absolute frequency; * Nonparametric Mann-Whitney Test. Value of $\mathrm{p}$ in bold italic indicates statistical association at the $5 \%$ significance level

$(45.0 \%)$ were cigarette smokers, demonstrating that multiple factors may contribute to the onset of these comorbidities in patients with psoriasis.

\section{CONCLUSION}

The occurrence of dyslipidemia and obesity in patients with psoriasis may alter the quality and expectancy of life of these patients, increasing the risk for cardiovascular diseases, making periodic investigation of these comorbidities mandatory, in addition to a multidisciplinary patient follow-up.
12. Alberti KG, Zimmet P, Shaw J; IDF Epidemiology Task Force Consensus Group. The metabolic syndrome - a new worldwide definition. Lancet. 2005;366:1059-62.

13. Ribeiro Filho FF, Mariosa LS, Ferreira SR, Zanella MT. Visceral fat and metabolic syndrome: more than a simple association. Arq Bras Endocrinol Metabol. 2006;50:230-8.

14. Naldi L, Chatenoud L, Linder D, Belloni Fortina A, Peserico A, Virgili AR, et al. Cigarette smoking, body mass index, and stressful life events as risk factors for psoriasis: Results from an Italian case-control study. J Invest Dermatol. 2005;125:61-7.

15. Cohen AD, Gilutz H, Henkin Y, Zahger D, Shapiro J, Bonneh DY, et al. Psoriasis and the Metabolic Syndrome. Acta Derm Venereol. 2007;87:506-9.

16. Sommer DM, Jenisch S, Suchan M, Christophers E, Weichenthal M. Increased prevalence of the metabolic syndrome in patients with moderate to severe psoriasis. Arch Dermatol Res. 2006;298:321-8.

\author{
MAILING ADDRESS: \\ Mônica Santos \\ Av. Pedro Teixeira, 25 - Dom Pedro \\ 69040-000 - Manaus - AM \\ Brazil \\ E-mail:m.n.souza.santos@gmail.com
}

How to cite this article: Santos M, Fonseca HM, Jalkh AP, Gomes GP, Cavalcante AS. Obesity and dyslipidemia in patients with psoriasis treated at a dermatologic clinic in Manaus. An Bras Dermatol. 2013;88(6):913-6. 